\title{
Bilateral femoral periostitis revealing polyarteritis nodosa
}

\author{
Sebastien Sanges, ${ }^{1}$ Noemie Le Gouellec, ${ }^{1}$ Elina Nedeva, ${ }^{2}$ Gregory Petyt ${ }^{3}$
}

${ }^{1}$ Department of Internal Medicine, National Centre for Rare Auto-Immune and Systemic Diseases, ClaudeHuriez Hospital, Regional University Hospital of Lille, Lille-Nord-de-France University, Lille, France

2Department of

Musculoskeletal Radiology and Imaging, Roger-Salengro Hospital, Regional University Hospital of Lille, Lille-Nord-deFrance University, Lille, France ${ }^{3}$ Department of Nuclear Medicine, Roger-Salengro Hospital, Regional University Hospital of Lille, Lille-Nord-deFrance University, Lille, France

\section{Correspondence to}

Dr Sebastien Sanges,

sebastien_sanges@msn.com
CrossMark

To cite: Sanges $S$, Le Gouellec N, Nedeva E, et al. BMJ Case Rep Published online: [please include Day Month Year] doi:10.1136/ bcr-2013-200695

\section{DESCRIPTION}

Periostitis of long bones is a possible yet rare manifestation of vasculitides such as polyarteritis nodosa (PAN). ${ }^{1}$ We report on a periostitis revealing a PAN, an exceptional situation. ${ }^{2}$

A man in his 40 s, with no medical record, presented with a 3-month history of bilateral leg pain, diffuse myalgias, weight loss and fatigue. Physical examination showed permanent pain in both thighs, with no signs of arthritis or muscle weakness. Erythrocyte sedimentation rate and $\mathrm{C}$ reactive protein (CRP) levels were elevated $(96 \mathrm{~mm}$ and $304 \mathrm{mg} / \mathrm{L}$, respectively). Immunological tests were found to be normal (antineutrophil cytoplasmic antibodies, antinuclear autoantibodies, complement, IgG, IgA and IgM levels).

Femoral X-rays were normal. Bone scintigraphy (figure $1 \mathrm{~A}-\mathrm{C}$ ), a useful first-line examination in detecting extra-articular involvement of inflammatory processes, ${ }^{3}$ showed uptake heterogeneities of both tracers on femoral diaphyses, due to inflammatory periosteal lesions, on whole-body scans obtained 6 (figure $1 \mathrm{~A}$ and $\mathrm{B}$ ) and $72 \mathrm{~h}$ (figure 1C) after injection of $580 \mathrm{MBq}$ of ${ }^{99 \mathrm{~m}} \mathrm{Tc}-\mathrm{HMDP}$ and $110 \mathrm{MBq}$ of ${ }^{67}$ Gallium. MRI of the lower limbs (figure 1D: short tau inversion recovery sequence, coronal section) showed circumferential hypersignals of femoral diaphyses, indicating active periosteal appositions. Quadricipital muscle biopsy showed no significant abnormality. An abdominal
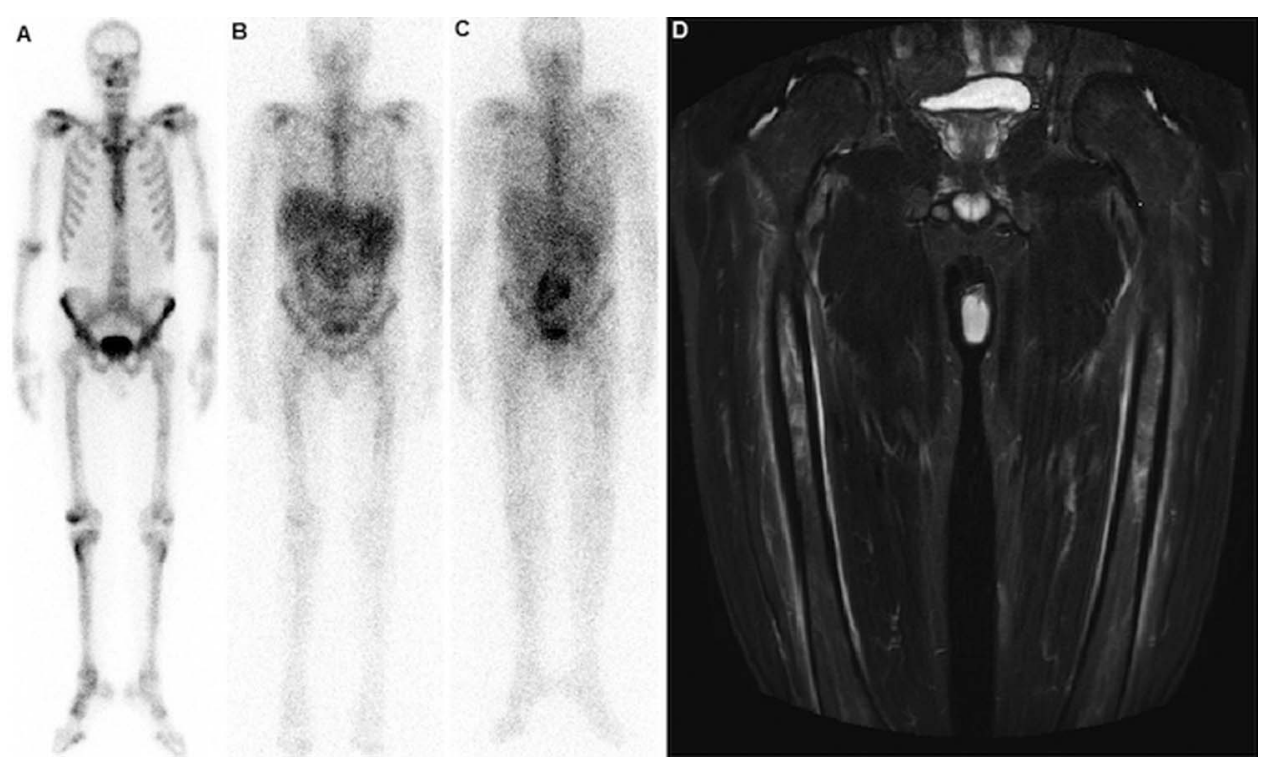

Figure 1 Scintigraphic and MRI aspects of femoral periostitis in polyarteritis nodosa $(\mathrm{A}-\mathrm{C})$. Whole-body scans obtained 6 (A and B) and $72 \mathrm{~h}$ (C) after injection of $580 \mathrm{MBq}$ of ${ }^{99 \mathrm{~m}} \mathrm{TC}-\mathrm{HMDP}$ and $110 \mathrm{MBq}$ of ${ }^{67}$ Gallium: mild uptake heterogeneities of both tracers on femoral diaphyses, due to inflammatory periosteal lesions. (D) MRI of the inferior limbs, short tau inversion recovery sequence, coronal section: circumferential hypersignal of both femoral diaphyses, indicating active-type periosteal appositions.
CT scan showed a left renal infarction and the coeliomesenteric arteriography, a left renal microaneurysm, confirming the diagnosis of PAN according to the 1990 American College of Rheumatology (ACR) criteria. Other explorations found no argument for another cause of periostitis (infection, neoplasm and other systemic diseases).

Oral corticosteroids (prednisone $1 \mathrm{mg} / \mathrm{kg} /$ day) led to a dramatic improvement of leg pain and weight loss. Twelve weeks later, the patient was asymptomatic and CRP was normal.

\section{Learning points}

- Systemic vasculitides, such as polyarteritis nodosa, must be included in the differential diagnoses of periostitis of long bones.

- Periostitis of long bones can be the revealing manifestation of PAN and the only sign of a relapse.

- Bone scintigraphy is a useful first-line examination in detecting extra-articular involvement of inflammatory processes.

Contributors The final version of the manuscript has been seen and approved by all the authors and they have given necessary attention to ensure the integrity of the work. 
Competing interests None.

Patient consent Obtained.

Provenance and peer review Not commissioned; externally peer reviewed.

\section{REFERENCES}

1 Perichon S, Pagnoux C, Seror R, et al. Periostitis in systemic necrotizing vasculitides: study of the 4 cases identified among the 1762 patients of the FVSG database and review of the literature. Presse Med 2010;39:e165-73.
2 Aries PM, Reuter M, Lamprecht P, et al. Periostitis as the initial manifestation of systemic vasculitis. Ann Rheum Dis 2005;64:329-30.

3 Caso F, Costa L, Atteno M, et al. The potential role of bone scintigraphy in the detection of deep muscular fascia involvement and calcinosis cutis in anti-synthetase syndrome. Int J Rheum Dis 2013;16:495-6.

Copyright 2013 BMJ Publishing Group. All rights reserved. For permission to reuse any of this content visit http://group.bmj.com/group/rights-licensing/permissions.

BMJ Case Report Fellows may re-use this article for personal use and teaching without any further permission.

Become a Fellow of BMJ Case Reports today and you can:

- Submit as many cases as you like

- Enjoy fast sympathetic peer review and rapid publication of accepted articles

- Access all the published articles

- Re-use any of the published material for personal use and teaching without further permission

For information on Institutional Fellowships contact consortiasales@bmjgroup.com

Visit casereports.bmj.com for more articles like this and to become a Fellow 